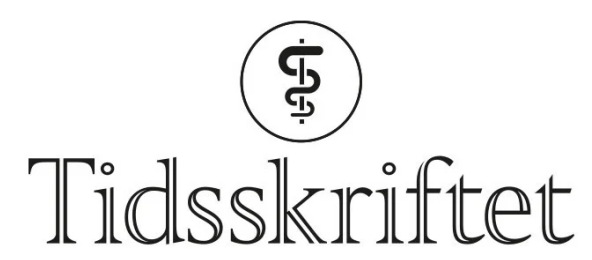

DEN NORSKE LEGEFORENING

\title{
Ingen gevinst av strålebehandling ved livmorkreft
}

NYHETER

MATILDE RISOPATRON BERG

Email: matilde.risopatron.berg@legeforeningen.no

Tidsskriftet

Langtidsoppfølging etter strålebehandling for endometriekreft viser økt hyppighet av sekundære kreftformer og ingen gevinst i overlevelse.

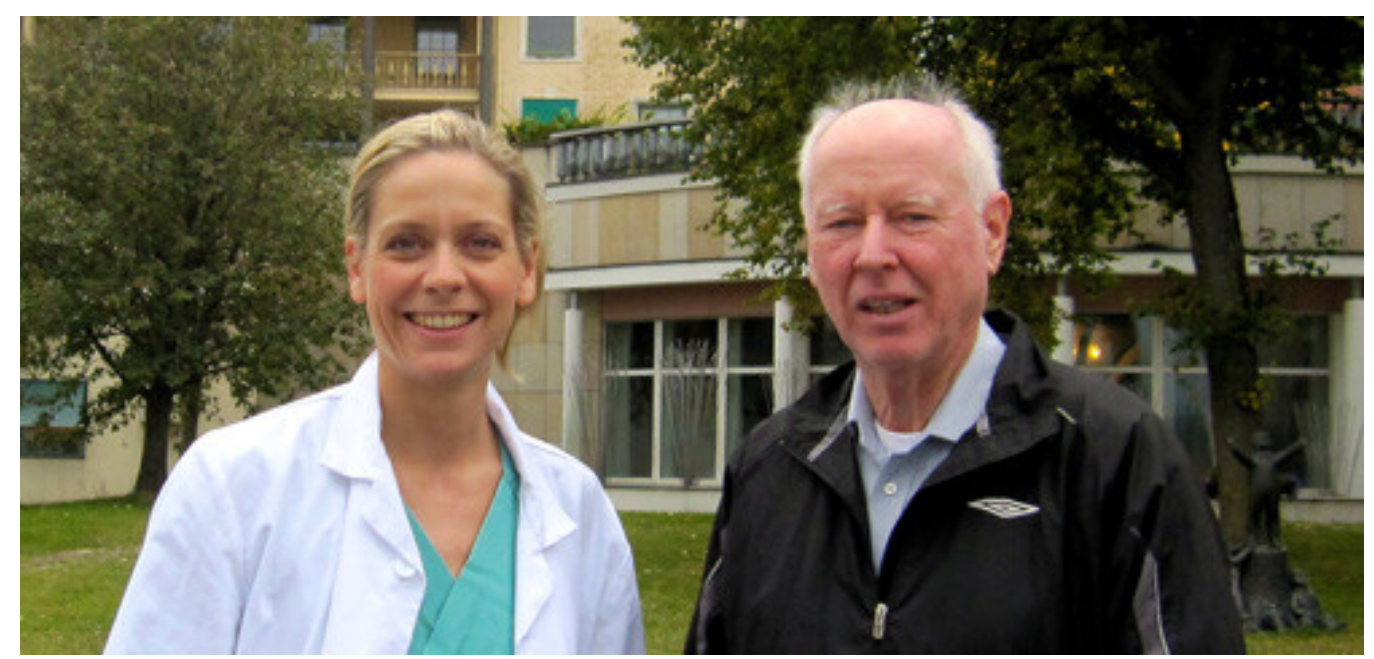

Sisteforfatter Kristina Lindemann og førsteforfatter Mathias Onsrud. Foto: privat

I en norsk studie som nylig er publisert i tidsskriftet Journal of Clinical Oncology ble langtidseffekten av strålebehandling mot endometriekreft i tidlig stadium studert (11). Studien er en oppfølging av den første randomiserte studien om slik behandling (므).

I perioden 1968-74 ble 568 kvinner etter operasjon og brakyterapi for endometriekreft randomisert til enten ekstern strålebehandling av bekkenet eller ikke. Kvinnene ble fulgt opp i 20,5 år (median). Strålebehandling ga ingen gevinst for overlevelse når hele gruppen ble regnet med (hasardratio 1,13; 95 \% KI o,96-1,35), mens kvinner som var yngre enn 6o år ved diagnosetidspunktet, hadde en signifikant høyere dødelighet (hasardratio 1,36; 95 \% KI 1,06-1,76) sammenliknet med dem som ikke fikk ekstern strålebehandling.

Strålebehandling ga også en signifikant $\emptyset$ kt risiko for sekundære kreftformer (hasardratio 
1,42; $95 \%$ KI 1,01-2,00), spesielt blant dem som var under 60 år på diagnosetidspunktet (hasardratio 2,02; $95 \% \mathrm{KI}$ 1,30-3,15). Økningen gjaldt særlig kreft som var lokalisert i strålefeltet, slik som tykktarm, urinblære og endetarm, og risikoen økte over tid.

- Dette er den første studien med langtidsdata som viser at ekstern strålebehandling ikke gir bedre overlevelse for kvinner med tidlig endometriecancer, sier Mathias Onsrud, som er professor emeritus ved Oslo universitetssykehus og førsteforfatter. Funnene bekrefter også epidemiologiske data om $\emptyset \mathrm{kt}$ forekomst av sekundærkreft etter strålebehandlingen.

- Studien viser at kvinner som tidligere har fått strålebehandling etter endometriekreft bør observeres nøye med tanke på kreft, og at ekstern strålebehandling kun bør brukes etter nøye overveielse, sier Onsrud.

\section{Mangeårig forskning ved Radiumhospitalet}

Den kliniske studien ble startet i 1968 av Per Kolstad, daværende sjef ved Gynekologisk avdeling ved Radiumhospitalet. Mathias Onsrud, den gang assistentlege, ble involvert, og har siden publisert flere artikler med utgangspunkt i studien, bl.a. sitt doktorgradsarbeid fra 1982 om effekten av strålebehandling på cellulær immunitet. Oppmuntret av professor og medforfatter Claes Tropé har han nå, etter 40 år, gått gjennom pasientmaterialet på nytt og sammenholdt data med informasjon fra Kreftregisteret og lokalsykehus. Prosjektet ble fullført i samarbeid med Kristina Lindemann som er overlege på Avdeling for gynekologisk kreft på Radiumhospitalet og som tidligere har disputert på fedme og risikoen for endometriecancer. Andre medforfattere er gynekolog Gunnar Kristensen, Milada Cvancarova Småstuen, som er kreftepidemiolog, og Taran P. Hellebust, som er medisinsk fysiker. 


\section{JOURNAL OF}

\section{CliniCAL}

\section{ONCOLOGY}

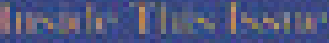

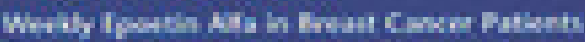

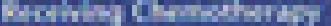

IHAirit

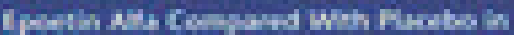

Anstring:

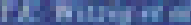

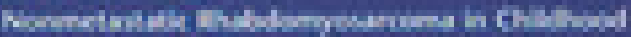

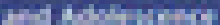

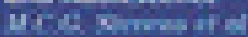

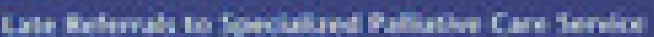

Hitwin

Priting

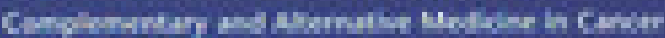
Prith hiph

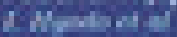

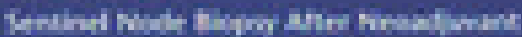

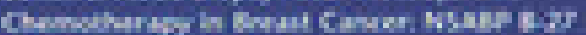

AP Mirminer

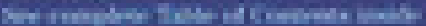

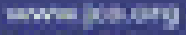

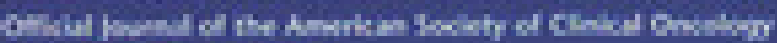

\section{ASCO}

Artikkelen ble e-publisert 9. september 2013 i Journal of Clinical Oncology

(http://jco.ascopubs.org/), som er ett av de høyest rangerte onkologiske tidsskriftene

\section{Ordforklaringer}

FIGO: The International Federation of Gynecology and Obstetrics.

Endometriecancer: Livmorkreft.

Brakyterapi: Brakyterapi er stråleterapi som gis ved at radioaktive kilder plasseres inni eller tett ved svulsten, i dette tilfellet i vagina.

\section{LITTERATUR}

1. Onsrud M, Cvancarova M, Hellebust TP et al. Long-term outcomes after pelvic radiation for earlystage endometrial cancer. J Clin Oncol 2013; e-publisert 9.9. 2013. [PubMed] [CrossRef] 
2. Aalders J, Abeler V, Kolstad P et al. Postoperative external irradiation and prognostic parameters in stage I endometrial carcinoma: clinical and histopathologic study of 540 patients. Obstet Gynecol 1980; 56: 419-27. [PubMed]

Publisert: 10. desember 2013. Tidsskr Nor Legeforen. DOI: 10.4045/tidsskr.13.1352

(C) Tidsskrift for Den norske legeforening 2023. Lastet ned fra tidsskriftet.no 26. april 2023. 